Discussion Paper No. 00-33

Collective Wage Agreements and Adjustments in German Services Firms

Ulrich Kaiser and Friedhelm Pfeiffer

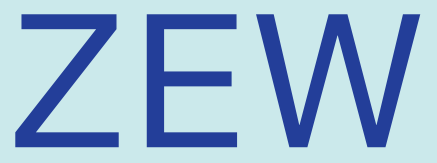

Zentrum für Europäische Wirtschaftsforschung GmbH

Centre for European

Economic Research 
Discussion Paper No. 00-33

\title{
Collective Wage Agreements and Adjustments in German Services Firms
}

\author{
Ulrich Kaiser and Friedhelm Pfeiffer
}

Download this ZEW Discussion Paper from our ftp server:

ftp://ftp.zew.de/pub/zew-docs/dp/dp0033.pdf

Die Discussion Papers dienen einer möglichst schnellen Verbreitung von neueren Forschungsarbeiten des ZEW. Die Beiträge liegen in alleiniger Verantwortung der Autoren und stellen nicht notwendigerweise die Meinung des ZEW dar.

Discussion Papers are intended to make results of ZEW research promptly available to other economists in order to encourage discussion and suggestions for revisions. The authors are solely responsible for the contents which do not necessarily represent the opinion of the ZEW. 


\title{
Collective Wage Agreements and Adjustments in German Services Firms
}

\author{
ULRICH KAISER* and FRIEDHELM PFEIFFER**
}

August 2000

\begin{abstract}
:
There is a growing concern about collective wage agreement and employment dynamics in Germany. In this paper, evidence is provided on the way collective wage agreements affect the adjustment of working hours, employment and other production factors when firms from the service sector are faced with demand shocks. The estimation results indicate that collective wage agreements significantly influence firms' employment policies. Enrolments and the employment of free-lance collaborators are negatively affected while the probability of using short-term employment contracts as a reaction to demand shocks is positively influenced. No significant effect on the probability of dismissing workers has been found.
\end{abstract}

JEL classification: C33, J30, J50

Keywords: collective wage agreements, demand fluctuations and adjustment costs, random effects ordered probit model, business-related services.

*Centre for European Economic Research, Germany.

**Centre for European Economic Research, P.O. Box 103443, D-68161 Mannheim, Germany, phone: 0049/621-1235-150; email: pfeiffer@zew.de

Acknowledgements: Financial support from the German Science Foundation (Deutsche Forschungsgemeinschaft, DFG) under grants FR715/3-1 and PF331/1-3 is gratefully acknowledged. The paper gained much from comments received at the 3rd Cologne-Bonn colloquium on personal economics held at Freiburg March 1 and 2, 2000 and from intensive discussions with colleagues from the Centre of European Economic Research. Our special thanks go to Bernd Fitzenberger and Wolfgang Franz for very helpful comments on an earlier draft of this paper. The usual disclaimer applies. 


\section{Introduction}

One of Germany's most challenging economic policy problem is its high rate of unemployment. While a number of European countries such as Denmark, The Netherlands and the United Kingdom have been successful in reducing their unemployment figures to rates of 4-6 percent, the portion of jobless workers has risen in Germany to over ten percent. It is often argued that the German labour market is too inflexible to substantially reduce unemployment rates. Above all, collective wage agreements are critically discussed in the economics profession.

In this paper it is analysed whether collective wage agreements actually influence firms' use of alternative instruments to adapt to product demand changes in a significant way. The focus is on the use of dismissals, enrolments, and on the adjustment of working hours when firms are confronted with demand variations. Since restrictions in firms' employment policies due to collective wage agreements may have secondary effects on the use of other instruments such as temporary employment contracts, subcontracting or price adjustments, these instruments to adjust to demand changes are also considered here.

Despite the ongoing public debate on labour market institutions and sluggish employment dynamics in Germany, empirical evidence on the way collective influence firms' employment decisions at the level of firms is scarce. A shortcoming of most of the existing studies on the relationship between labour market institutions and employment is that they focus on the sector level althoygh the firm is the place where hiring and firing decisions actually take place. An exception, however, is the contribution by Sadowski et al. (1995) who analyse the effect of the work councils on the competitiveness of German firms. The authors find that job turnover and dismissals are lower in firms where workers are represented by work councils than in firms where a work council does not exist. Another drawback of most existing studies is that a vast majority is solely concerned with manufacturing industries although in industrialised countries the service sector nowadays is more important than manufacturing industries in terms of overall economic significance. Both shortcomings are overcome in this paper: we analyse the effect of collective wage agreements for the German business-related services sector using firmlevel data.

\footnotetext{
${ }^{1}$ See Layard and Nickell (1999) for a critical discussion of alternative institutional labour market settings and detailed descriptive evidence on international labour markets.

${ }^{2}$ For evidence from German sector data see Franz and Smolny (1994), Houseman and Abraham (1995), Kraft (1989) as well as König and Pohlmeier (1988). For international studies see Hamermesh (1993) and Davis and Haltiwanger (1999). More recently, the interest of researchers has shifted to the firm-level. Reviews of this literature are presented by Hamermesh and Pfann (1996) and Franz (1999).

${ }^{3}$ Note that collective wage agreements have, if they exist, a legal priority over plant-level work agreements. See Rieble (1996) for a discussion of the German legal system governing the relationship between employers and employees.
} 
From an economic point of view the distinction between economic and institutional determinants of costs and their consequences for labour demand at the micro and the macro level is at the heart of the debate on labour market flexibility in Germany. Institutional arrangements like collective wage bargaining and employment protection laws can raise labour costs and the costs of adjusting working hours and employment to levels which hampers firms' employment dynamics. Our data set, the 'Service Sector Business Survey' (SSBS), a quarterly business survey in ten business-related services sector provides an ideal database for the study of institutional adjustment costs on labour dynamics for at least three reasons: first, business-related services is a fast growing sector of the German economy. In West Germany, the number of employees in business-related services grew by 88 percent between 1982 and 1996 (Kaiser et al., 2000). The business-related services sector therefore accounted for roughly six percent of total employees in West Germany in 1996. It now is of almost equal importance as the banking and insurance sector in terms of employment. Second, service firms differ markedly from manufacturing firms in their ability to adapt to demand shocks: production to stock is infeasible for them while it is a widely applied tool in manufacturing industries. Therefore, collective wage agreements should have a more direct effect on labour demand in services than in manufacturing. Third, compared to the manufacturing sector, there is a relatively low diffusion of collective wage agreements in the business related service sector. According to calculations on the basis of the SSBS survey of summer 1999, on average only 38 percent of total sales in the business-related services sector is realised by firms bound to collective wage agreements (see Table 1). For reasons of comparison, Table 1 also contains the coverage of employees in collective wage agreement calculated from the Institute for Employment Research's (IAB) establishment panel for 1998 (Bispinck, 1999, p. 10; see also Bellmann et al., 1999). In West Germany, collective wage agreements cover 67.8 percent of the employees, in East Germany 50.5 percent. In the service sector, the overall coverage is 55.2 percent in West Germany and 45.6 percent in East Germany.

The figures from the SSBS and the IAB establishment panel are not directly comparable since the SSBS figures are related to sales while the IAB figures are related to the number of employees. It clearly is nevertheless indicated that the diffusion of collective wage agreements is lower in the service sector than in the total economy. It is very low in most of the fast-growing business related services sectors. One reason for the below-average validity of collective wage agreements in the business-related services sector as displayed in Table 1 (e.g., in tax consultancy it is $4.5 \%$ ) is that explicit collective wage agreements do not

\footnotetext{
${ }^{4}$ The SSBS is collected by the ZEW in co-operation with Germany's largest credit rating agency Creditreform since June 1994. Business-related services in Germany are defined by Klodt et al. (1997) by enumeration of the following sectors (see Table 1): (1) computer and related activities, (2) tax consultancy, (3) management consultancy, (4) architectural activities, (5) technical consultancy, (6) advertising, (7) renting of automobiles, (8) renting of machinery, (9) cargo handling and storage and (10) sewage and refuse disposal.
} 
exist in many of these sectors. ${ }^{6}$ Another reason is that the share of highly skilled labour in business-related services is up to four-times as large than that of manufacturing industries (33.2 \% vs. $8.7 \%$, Pfeiffer and Falk, 1999). Compared to skilled workers ('Facharbeiter') university graduates are less likely to be union members (Fitzenberger et al. 1999). According to the econometric results in Section 5, the negative relation between firms' share of highly skilled labour and the probability that it applies collective wage agreements is confirmed for the German business-related services sector.

Table 1: Share of Firms Applying Collective Wage Agreements

Business-related services (SSBS,1999): as percentage of total sales

\begin{tabular}{lc}
\hline & sales share \\
Tax consultancy & 4.5 \\
Advertising & 13.4 \\
Vehicle rental & 16.2 \\
Management consultancy & 22.3 \\
Architectural activities & 25.8 \\
Computer \& related activities & 29.7 \\
Machine rental & 37.2 \\
Techn. consultancy & 41.1 \\
Cargo handling & 73.6 \\
Sewage disposal & 74.0 \\
Business-related services (total) & 37.9 \\
Business-related services (East Germany) & 37.7 \\
Business-related servcies (West Germany) & 37.9 \\
Selected sectors (IAB establishment panel, 1998): as percentage of total \\
\hline
\end{tabular}

German unions currently undergo a process of reorganisation and structural change. In order to increase their influence in the German service sector, they plan to unify five individual unions into a single service uniop called 'verdi' which will presumably have more than three million members. The foundation conference is scheduled to take place in March 2001. If the unions are actually successful in increasing their economic relevance, the diffusion of collective wage agreements will rise in the future. The question then arises is whether

\footnotetext{
${ }^{5}$ Firms are allowed to adopt collective wage agreements of other sectors, which, however, is rarely the case.

${ }^{6}$ For more information, visit the verdi website at http://www.verdi-net.de/.
} 
such a development will have consequences on labour demand in the service sector, both in the short and in the long run.

Main results of this paper are that collective wage agreements induce firms to react in an asymmetric way to product demand shocks. Firms applying collective wage agreements significantly less often hire additional labour and free-lance collaborators to cope with demand fluctuations than firms not bound to such contracts. The probability of short-term employment contracts is positively affected while collective wage agreements have no impact on dismissals. Additional adjustment costs which are imposed on the change of employment and hours of work by collective wage agreements are presumably responsible for these results.

The paper proceeds as follows: Section 2 introduces a framework for discussing the influence of collective wage agreement on the adjustment of hours, employment and other instruments of firms faced with demand variations and surveys the literature. Section 3 describes the econometric model and Section 4 introduces the data. Section 5 presents estimation results and Section 6 concludes.

\section{Adjustment costs, collective wage agreements and labour demand}

\section{Economic and institutional adjustment costs}

If firms' reality could be best described by the standard economic textbook model of perfect competition on in- and output markets, then optimal adjustment of all input factors would take place instantaneously. It has long been recognised that this in fact is not the case (see Hamermesh, 1993). The demand for labour and other factors usually adjusts more slowly than the demand for firms' output. Adjustment costs smooth the time path of inputs. The larger the cost of adjusting input factors is, the slower will the adjustment of inputs on average be if firms are faced by product demand shocks. Firms tend to hoard labour in recession phases and/or use overtime work or inventories of goods to cope with rising demand. In the service sector, the use of inventories, however, is limited. The service of architects, consultants or vehicle renters cannot be stored. This characteristic of services therefore reduces the flexibility of firms to variations of input factors.

In labour demand theory, two broad categories of costs are defined: variable and fixed costs (Hamermesh, 1993). Variable costs vary with the amount of labour employed, fixed costs do not change. The functional form and the composition of fixed and variable labour costs and other factor costs determine the adjustment costs of changing labour and thereby the dynamic path of working 
hours, employment and other inputs factors in reaction to demand fluctuations (see Hamermesh and Pfann, 1996). Both types of costs can be influenced by economic factors, for example rising energy prices or changes in the skill composition of labour supply, and institutional arrangements like collective wage agreements, employment protection laws or work councils. In Germany, workers can be represented by a work council at the firm level and by unions at the sector level, which has been called the "duality of workers representation" (see Sadowski et al., 1995). While work councils have a strong legal position with respect to dismissals and hours of work, collective wage agreements (bargained between unions and employer's associations or unions and single firms) have, however, a legal priority over plant-level arrangements (bargained between work councils and firms or between workers and firms) (see Rieble, 1996).

The distinction between economic and institutional determinants of costs and their consequences for labour demand is important for the debate on labour market flexibility. Institutional arrangements can raise fixed costs to levels which might hamper employment dynamics. Furthermore, collective wage bargaining might result in a wage structure which is not compatible with full employment (for a more detailed discussion on the German experience, see Fitzenberger and Franz, 1999). Economic factors may also result in high and rigid levels of fixed and variable costs. Informational theoretic reasons for example might lead to efficiency wages. Hence, it is not the absolute importance of institutional adjustment costs that matters but its relative or differential importance and its interplay with economic adjustment costs.

Economic fixed costs can arise due to employee-specific human capital which result from the individual employer-employee relationship. A fraction of these costs like search and other enrolment costs have to be borne before the worker actually is employed, another fraction is generated during the relationship by, e.g., employee training. Institutional costs may result from the German system of employment legislation in general, and, more specifically, from collective wage agreements. The latter ones determine specific infrastructure investments for handicapped persons, safety provisions for workers and the costs of dismissing a worker. In Germany, dismissed workers are entitled to compensation payments which depend on tenure and family status ('Kündigungsschutzgesetz', see Houseman and Abraham, 1995). Firms which apply collective wage agreements in addition often accept special employment protection rules that rule out for example dismissals of older employees caused by rationalisation. The adjustment of hours might also induce specific costs, which can depend on statutes formalised in a collective wage agreement. Many agreements include paragraphs which restrict the amount of overtime work and/or determine the level of additional overtime pay (see Bispinck, 1999). 
Fixed costs associated with an adjustment of employment and working hours arise during the entire length of the employee-employer relationship, whether they originate in economic or institutional reasons. It follows that wages at times will be lower than the worker's marginal product of labour and that economic shocks must be larger to lead firms to adjust the higher the adjustment costs. A brief discussion of Farber's (1999) illustrative model is helpful in capturing the key concepts and costs in the adjustment of employment and in deriving testable hypothesis for the empirical analysis. ${ }^{\text {Let }} Y$ denote the total value of the specific human capital inherent in the individual match between an employer and an employee. The firm has to pay to the worker a wage $W$ of

$$
\text { (1) } W=W_{a}+\lambda Y \text {, }
$$

where $W_{a}$ is the worker's outside wage and the wage the firm would have to pay in the case of enrolments. $\lambda$ can vary between 0 and 1 and denotes the employee's share of the value of the specific capital. The value of what the worker produces is

$$
\text { (2) } V=W_{a}+Y+\phi \text {, }
$$

where $\phi$ denotes a random variable with mean zero which influences the value of the employment relationship. The variable represents economic shocks which stem, for example, from demand fluctuations or from changes in input prices. Subtracting the wage rate $W$ from $V$ leads to firm's profit with respect to the individual employee-employer relationship:

$$
\text { (3) } \Pi=V-W=W_{a}+Y+\phi-W_{a}-\lambda Y=(1-\lambda) Y+\phi \text {. }
$$

From (3) it follows that firms lay off workers as a result of a demand shock if

$$
\text { (4) } \phi<-(1-\lambda) Y \text {, }
$$

that is, if the profits out of the individual employee-employer relationship are negative. Note that the outside wage $W_{a}$ cancels out. Dismissals as a result of demand fluctuations are more likely the larger $\lambda$ or the lower the value of the specific capital inherent in the employee-employer relationship is. In the SSBS data, one observes to what extend dismissals or enrolments are applied by firms in order to react to demand changes. If dismissals (enrolments) are used by the firm, the profit generated by the laid off worker is negative (positive). Equation (4) captures the nature and the effect of adjustment costs on layoffs and enrolments, whether they origin in economic or institutional factors, in an instructive way. ${ }^{-}$This relationship is helpful in deriving testable hypotheses on firm behaviour and in organising the empirical part of the study.

\footnotetext{
${ }^{7}$ For space reasons, the argumentation is restricted to the demand side. For a discussion of supply side effects see Farber (1999) or Franz (1999). The empirical model (see section 3 and 4) implicitly takes into account both demand and supply side effects by controlling for observed and unobserved firm heterogeneity. Note also that the issue of adjustment costs is not restricted to labour and can be discussed in a comparable way for capital or other input factors as well.

${ }^{8}$ For structural models of collective wage bargaining in Germany see Fitzenberger and Franz (1999).
} 
The gains from an employer-employee match (equation 4) depend on the degree of competition on in- and output markets, on the degree of substitution between labour and capital and, in the case of heterogeneous labour, on the degree of substitution between different skill levels and on other working conditions, which stem from labour market institutions. Collective wage agreements in Germany can influence $\lambda$ and/or $Y$ in different ways. Collective wage bargaining in Germany is not restricted to wages only. Working conditions such as specific employment protection rules and restrictions in hours of work are part of the negotiation and might enhance the value of $\lambda$ and/or $Y$. Collective wage agreements are the results of bargaining between a union and an employer association or between an union and a single firm. The agreement therefore is in the interest of the signing employer association and unions and the results of negotiation typically will contain compromises in case of conflicting interests between bargaining parties.

In what follows it is assumed that employed workers and their unions are interested in stable, long-term employer-employee relationships for their members. More stable employment relationships might on average be also in the interest of successful firms applying collective wage agreements. A larger value of $Y$ and/or a smaller value of $\lambda$ is helpful in achieving the goal of longterm employee-employer relationships of the workers employed in the face of variations in demand. Training at the workplace for example can raise the value of $V$. Evidence from international empirical studies on the determinants of work-related training supports this view. In firms where unions have more influence - which likely is the case if firms participate in collective wage bargaining -, the individual likelihood of participating in work-related training is larger than in firms which do not apply collective wage contracts (see Pfeiffer, 2000).

As a consequence of applying collective wage agreements, the employeremployee relationship in firms applying collective wage agreements will, under the further assumption that shocks are not specific to firms applying collective wage agreements, be more stable on average than in firms not applying collective wage agreements. Economic shocks have c.p. to be larger in firms

\footnotetext{
9 German basic constitutional law ('Grundgesetz') allows the creation of coalitions ('Koalitionsfreiheit', Article 9). Workers can bundle their interests in unions and bargain with firms. Alternatively is possible to leave the union and bargain individually. From a legal point of view, firms participating in collective wage agreements only have to apply the results of the collective bargaining process to workers who are members of the bargaining union. This, however, does not create problems for the empirical analysis below since in Germany firms actually apply the outcome of collective wage agreements to all of their workers (see Fitzenberger and Franz, 1999). It therefore does not make a difference if an individual worker in a firm applying collective wage agreement belongs to the union or is not a union member.
} 
participating in collective wage agreement than in other firms to lead firms to adjust labour. Hence, our first hypothesis is that firms applying collective wage agreement have a lower probability of using the instrument of enrolments when confronted with (positive) demand shocks (see Table 2). If $\lambda$ and/or $Y$ is higher due to collective wage agreements, than the positive shock which leads to enrolments has to be larger in these firms compared to other firms.

A symmetric argument does not necessarily apply to dismissals and negative demand shocks. On the one hand, it is true that negative demand shocks must be larger for firms applying collective wage contracts before they dismiss workers. On the other hand, for firms applying collective wage agreements, the values of $\lambda$ and/or $Y$ might be more rigid downwards than in other firms. Downward flexibility might counteract negative shocks at least to some degree. If in firms which are not bound to collective wage agreement the values of $\lambda$ and/or $Y$ are more flexible downwards, ${ }^{\text {to }}$ the employment consequences of negative shocks might be dampened. In recent times, collective wage agreements in some sectors contain hard-ship clauses, which allow firms to reduce wages in case of negative economic developments (see Bispinck, 1999). Hard-ship clauses are more often contained in collective wage agreements in East than in West Germany. The firm's work council has to agree upon the application of a hardship clause. There is, however, no empirical evidence of the application of hardship clauses to date. Summing up, our hypothesis with respect to dismissals is not as clear-cut as the one related to enrolments. Collective wage agreements may have positive or negative impacts on dismissals. In fact, work councils might also have a differential influence on firms' employment policies. The SSBS, however, does not contain information on work councils.

Firms use more than just the instruments of dismissals and enrolments to adapt to demand changes. They may alternatively or additionally use the following instruments which are observed in the SSBS: (1) overtime/short-time work, (2) life-long working schemes, (3) temporary employment contracts, (4) subcontract orders, (5) free-lance collaborators and (6) price adjustments. These instruments may be influenced by collective wage agreements either in a direct way such as overtime work and life-long working schemes or in an indirect way such as temporary employment contracts, free-lance collaborators or price adjustment which are not part of the wage bargaining.

Our hypotheses with respect to the influence of collective wage agreements on the use of these instruments shall be briefly illustrated (see Table 2). Unions have an interest in reducing working time (without pay losses) and the amount of overtime work since that may result in more stable employment relationship

\footnotetext{
${ }^{10}$ There are economic reasons as well that labour adjustment as a result of positive or negative shocks is not symmetric (see Hamermesh and Pfann, 1996). Therefore the sources of downward rigidities of wages remains an empirical question.
} 
for their members. $\square$ Hence, our hypothesis is that firms which apply collective wage agreements less frequently use overtime/short-time work as a reaction to demand changes. 2

Given that unions are interested in durable employer-employee relationships, it seems likely that they favour life-long working hours schemes. This is enforced by a tendency in collective wage agreements to reduce overtime pay and to increase the flexibility of hours arrangements, which is in the interest of firms. Our hypothesis is that firms applying collective wage agreements have a higher probability of using life-long working hours schemes than firms not applying collective wage contracts.

Table 2: The expected signs of the impact of collective wage agreements on firms' use of alternative instruments for coping with demand fluctuation

\begin{tabular}{l|c} 
Instrument & Expected sign \\
\hline Enrolment & - \\
Dismissal & $-/+$ \\
Overtime/short-time & - \\
Life-long working schemes & + \\
Temporary employment & + \\
contracts & \\
Free lance contractor & - \\
Subcontracting & + \\
Price adjustments & 0
\end{tabular}

Temporary employment contracts are not subject to collective bargaining rounds. Therefore the influence of collective wage agreements on the use of temporary employment contracts is of secondary nature. Such working contracts are likely to be applied if firms are uncertain about the lasting nature of a product demand shock. Since firms which are bound to collectively bargained wages and hours agreements have a higher need for flexibility, it is hypothesised that collective wage agreements have a positive effect on the use of temporary employment contracts.

Subcontracting orders to other firms is another flexible instrument for firms to react to demand changes, which is not part of collective wage bargaining. If

\footnotetext{
${ }^{11}$ Whether employment rises as a consequence of a reduction of the amount of overtime work, however, depends among others on the technology of the firm, on wages and on demand side conditions (Franz, 1999). König and Pohlmeier (1988) and Kraft (1989) found that a reduction in working times actually slightly reduced employment for manufacturing industries.

${ }^{12}$ From a theoretical point of view the effects of collective wage agreements on overtime and short-time work may differ. Because of data limitations we are unfortunately not able to separate these effects.
} 
firms applying collective wage agreements are restricted in the adjustments of labour and working hours, subcontracting orders also should be used relatively more often by firms bound to collective wage agreements. Although the same reasoning holds for free-lance workers ('freie Mitarbeiter') - which is in fact nothing but a special form of subcontracting from an economic point of view -, we nevertheless hypothesise that the probability of the use of this instrument is lower for firms bound to collective wage agreements. In Germany there has been a debate about the emergence of "false" self-employment since several years. WSince self-employed workers cannot be union members, we hypothesise that collective wage agreements have a negative effect on the use of free-lance workers if faced by demand shocks.๑

The last instrument analysed is price adjustment. If collective wage agreement and non-collective wage agreement firms operate on comparable markets, the impact of collective wage agreement on the use of price adjustments should be zero. The empirical results therefore could be understood as a test of the assumption that applying collective wage agreements is not related to price setting power on product markets.

\section{Microeconometric approach}

The employer-employee specific profit $Y(1-\lambda)$ for the firm (see equation (4)) cannot be observed in the SSBS data. The condition for firing and hiring workers as stated in equation (4) can, however, be translated into a latent model, where the use of enrolments due to demand shocks is represented by a latent variable. In the SSBS data, the extent to which firms use alternative instruments to adjust to demand fluctuations are reported on an ordinal five-point scale. An ordered probit model therefore is an adequate device for the econometric analysis.

From the theoretical reasoning it followed that firms' application of dismissals and enrolments are determined by the relative magnitudes of $Y(1-\lambda)$ and the demand shocks. The values $Y(1-\lambda)$ are determined by the firms' technology, the price elasticity of product demand, the degree of competition on the product market, input prices, and skill composition as well as by institutional factors such as collective wage agreements. Some of these factors, like the skill structure and collective wage agreements, are observed in the SSBS data,

\footnotetext{
${ }^{13}$ See Dietrich (1998). A worker is said to be false self-employed if she or he is doing work which usually is done by employees. Workers and firms might have an incentive for false self-employment to save taxes and contributions to the social security systems. The German government enacted more stringent rules to hamper the development of false self-employment in order to stabilise regular employment in 1999.

${ }^{14}$ Unions are aware that subcontracting orders to firms which are not bound to collective wage agreements are a way of surrounding collective wage agreements. Therefore one goal of unions is to expand the validity of collective wage agreements also to subcontracting firms.
} 
others, like the price elasticity of demand and technology, are not available. In the econometric model observed and unobserved firm heterogeneity is taken into account by including a set of control variables and by capturing random firm-specific effects.

It is assumed that the observed variable $Z_{i}-$ in the present case, firm i's ordinal use of enrolments etc. - takes on the value 1 if a latent variable $Z_{i}^{*}$ lies in between the boundaries $\mu_{l-1}$ and $\mu_{l}$, where $l=1, \ldots L$ and $L$ denotes the total number of values the observed variable $Z_{i}$ takes on. The latent variable $Z_{i} *$ is assumed to be linearly related to a set of explanatory variables, summarised in the column vector $x_{i}$, by a column vector $\beta$ and an i.i.d. normal distributed error term $v_{i}: Z_{i}^{*}=x_{i}^{\prime} \beta+v_{i}$. Comparisons of the estimated vector of coefficients, $\hat{\beta}$, across different ordered probit models are infeasible due to the identification problem in qualitative dependent variable models. For three possible states, e.g., non-application of enrolments $\left(Z_{i}=0\right)$, occasional application of enrolments $\left(Z_{i}=1\right)$, and application of enrolments $\left(Z_{i}=2\right)$, the relationship between the latent variable $Z_{i}{ }^{*}$ and the observed variable $Z_{i}$ can be summarised as:

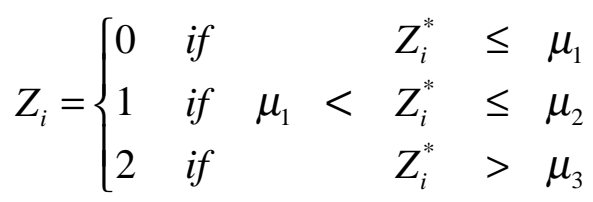

i.e., firms indicate that they often apply enrolments $\left(Z_{i}=2\right)$ if the latent value $Z_{i}$ * exceeds the critical value $\mu_{2}$. In this case, the latent variable can be regarded as the intensity of firms' enrolments which is transferred by the interviewee to an ordinal scale. The inclusion of the variables for observed firm heterogeneity such as firm size and sectoral affiliation and the inclusion of firm size dummies is equivalent to allowing the thresholds $\mu$ to vary dependent on observable firmspecific factors. If, as in the present case, $x_{i}$ includes a constant term, one threshold has to be normalised in order to yield identification. Without loss of generality $\mu_{.1}=0$ is chosen. The probability to observe $Z_{i}$ taking on the value 0 , 1 or 2 , conditional on the set of explanatory variables $x_{i}$, is:

\footnotetext{
${ }^{15}$ For the extreme values, $Z_{i}=0$ and $Z_{i}=L$, the related boundaries are $\mu_{0}=-\infty$ and $\mu_{L}=\infty$.

${ }^{16}$ Note that the normality assumption is a weak one since "(...) shifting the boundaries can make ordered probit fit any multinomial distribution" (Hausman et al., 1992, pp. 325-326).

17 The standard error of the disturbance term, $\sigma$, is not identified so that the elements of the estimated parameter vector are all scaled by $\sigma$.

18 Alternatively, identification is also obtained if the thresholds are be set to some arbitrary value and the specification includes a constant term both in the conditional variance and in the conditional mean.
} 


$$
\operatorname{Pr}\left(Z_{i}=l \mid x_{i}\right)=\left\{\begin{array}{c}
\operatorname{Pr}\left(\frac{x_{i}^{\prime} \beta+v_{i}}{\sigma} \leq \frac{\mu_{1}}{\sigma}\right) \quad \text { if } \quad l=0 \\
\operatorname{Pr}\left(\frac{\mu_{1}}{\sigma}<\frac{x_{i}^{\prime} \beta+v_{i}}{\sigma} \leq \frac{\mu_{2}}{\sigma}\right) \text { if } \quad l=1 \\
\operatorname{Pr}\left(\frac{x_{i}^{\prime} \beta+v_{i}}{\sigma}>\frac{\mu_{2}}{\sigma}\right) \quad \text { if } \quad l=2
\end{array}\right.
$$

cumulated standard normal distribution, one can rewrite equation (6) as:

$$
\operatorname{Pr}\left(Z_{i}=l \mid x_{i}\right)=\left\{\begin{array}{ccc}
\Phi\left(\frac{\mu_{1}-x_{i}^{\prime} \beta}{\sigma}\right) & \text { if } & l=0 \\
\Phi\left(\frac{\mu_{2}-x_{i}^{\prime} \beta}{\sigma}\right)-\Phi\left(\frac{\mu_{1}-x_{i}^{\prime} \beta}{\sigma}\right) & \text { if } & l=1 \\
1-\Phi\left(\frac{\mu_{2}-x_{i}^{\prime} \beta}{\sigma}\right) & \text { if } & l=2
\end{array}\right.
$$

where $\sigma$ denotes the standard error of the disturbance term $v_{i}$ which is usually, as in the present application, normalised to one. The formulation of the ordered probit model as in equations (5) to (7) can be extended to panel data applications in a straightforward way. In the SSBS, each firm $i$ is observed one to four times. The latent variable associated with an ordered panel data model, $Z_{i t}{ }^{*}$, where the subscript $t$ denotes the point in time at which firm $i$ is observed, is now given by $Z_{i t}{ }^{*}=x_{i t}{ }^{\prime} \beta+v_{i t}$. The error term $v_{i t}$ is specified as the sum of two components: $v_{i t}=\varepsilon_{i t}+\alpha_{i}$. $\alpha_{i}$ is assumed to be a time independent individualspecific random variable, reflecting unobserved firm heterogeneity, while $\varepsilon_{i t}$ is assumed to be an error term which is independent both across individuals and across time. Both error terms are assumed to be normally distributed with zero means. In order to yield identification of the model, the standard error of $\varepsilon_{i t}, \sigma_{\varepsilon}$, is normalised to one. Hence:

$\operatorname{Var}\left[v_{i t}\right]=\sigma_{\varepsilon}^{2}+\sigma_{\alpha}^{2}=1+\sigma_{\alpha}^{2}$ and $\operatorname{Corr}\left[v_{i t}\right]=\rho=\frac{\sigma_{\alpha}^{2}}{\left(1+\sigma_{\alpha}^{2}\right)}$ with $t^{\prime} \neq t$.

The parameter $\sigma_{\alpha}^{2}$ has to be estimated. ${ }^{1}$ The relevance of the panel structure, that is, the difference between the full (random effects) and the restricted (pooled) model, is tested.

\footnotetext{
${ }^{19}$ The derivation of the corresponding likelihood-function is discussed for example by Greene (1997, ch. 19.8) Hamerle and Ronning (1995) discuss the random effects ordered probit model in greater detail. All estimations were run using the software package LIMDEP 7.0 (Greene, 1995).
} 


\section{Data}

The data are taken from the ZEW Service Sector Business Survey (SSBS). The SSBS is a random sample, stratified with respect to ten service sectors as well as with respect to regional affiliation (East/West Germany) and firm size. The ZEW has been sending out a one-page questionnaire every three months to about 3,500 firms belonging to the business-related services sector since the second quarter of 1994. Over the past six years, the response rate has remained quite constant at around 30 percent. The survey is constructed as a panel, e.g., the same firms are repeatedly sent a questionnaire. The questionnaire is divided into two parts. In the first part, firms are asked to indicate on a three-point Likert scale whether their sales, prices, demand, profits and number of employees have, in the respective previous quarter, either increased, remained unchanged, or decreased. Moreover, they are asked to give an assessment of the five indicators for the coming quarter. The second part of the survey deals with economic and political issues of interest, some of them are repeated on an annual basis. Our analysis is based on the SSBS data related to the fourth quarters of 1996, 1997, 1998, and 1999, e.g., to waves 11, 15, 19 and 23 of the SSBS. The ZEW has been annually asking about the extent to which firms use instruments to adapt to demand changes in the respective fourth quarters since 1996. It was allowed for multiple responses. The responses range from 'not applied at all' to 'very often applied' on a five-point Likert scale.

Table A1 in the Appendix displays descriptive statistics on the distribution of answers across the alternative instruments in each wave. Overtime/short-time work is by far the most often applied method to adjust to demand changes. In 1999, 43.9 percent of the firms apply overtime/short-time work. Life-long working hours schemes on the other hand are comparably seldom used. 60 percent of the firms do not apply them at all. Temporary employment contracts, subcontracting and free-lance employment are both either applied or often applied by roughly a quarter of firms. Around 18 percent applies enrolments and eleven percent applied dismissals. While 43 percent of the firms never apply dismissals as an instrument to cope with demand fluctuations, only a quarter never applies enrolments. Price adjustments are applied by 17 percent of the firms in the sample. While the time pattern of the use of most instruments seems to be rather stable, the number of firms applying enrolments has risen between 1996 and 1999, which indicates the dynamic nature of this sector of the economy. The figures confirm results found in the literature that the adjustment of hours usually is more often used than the adjustment of employment (Hamermesh, 1993). Price-adjustment and life-long working hours schemes are less often applied while subcontracting and temporary employment contracts is a quite common instrument. The variety of instruments used indicate firms'

\footnotetext{
${ }^{20}$ Details on sample stratification and the calculation of expansion factors are presented in Kaiser et al. (2000).
} 
effort to gain flexibility. If some instruments are restricted by law, economic forces or institutions for whatever reason, this might have consequences for the use of these and the other instruments.

The information on whether firms apply collective wage agreements is taken from the 21st wave of the SSBS (2nd quarter of 1999), i.e., collective wage agreements are treated as a time-invariant variable. It includes firms which apply collective wage agreements voluntary or as a member of the employers' association. It is not restricted to central wage agreements ('Flächentarifvertrag') only and also includes firms which directly bargain with unions ('Firmentarifvertrag'). The German Ministry of Labour can declare centrally bargained wages and other working conditions as legally binding for all firms in special sectors ('Allgemeinverbindlicherklärung'). In the ten sectors analysed in the SSBS there currently are no such binding declarations. Roughly 62 percent of the business-related services firms in our sample negotiate wages between employers and employees, that is without unions. Among them, 87.6 percent negotiate individual wage contracts.

It is assumed that firms which were bound to collective wage agreements in the 21 st wave also applied collective wage agreements in the previous and later waves used in this study, i.e., waves $11,15,19$ and 23 . According to recent evidence by Bellmann et al. (1999) more than 90 percent of firms applying a collective wage agreement in 1995 (1996) also applied collective wage contracts in 1996 (1997) in West Germany. Furthermore, it was found that firms which exited collective wage agreements in some year, often returned to the application of collective wage agreements in later years. In East Germany, the fluctuation in the application of collective wage agreements has been somewhat larger than in West Germany. One can therefore not exclude the possibility that there are firms in the SSBS sample which did not apply a collective wage agreement in 1999 but did so in previous years, and vice versa. However, by keeping in mind that entry and exit into or from collective bargaining is modest, the potential errors-in-variables-problem should be rather small.

The empirical model assumes that the extent to which the instruments are used to cope with demand variations is determined by (for descriptive statistics, see Table A1 in the Appendix):

(1) The validity of a general wage agreement. This is a dummy variable which is coded one if the firm is bound to a general wage agreement. The variable is denoted by COLLWAGE.

(2) Labour force composition. Information collected in the SSBS-waves 16, 18 and 20 is employed to calculate the share of high skilled (university and polytechnics graduates) and low skilled (workers with no formal qualification) labour in firms' total employment. The share of highly skilled 
labour is denoted by $S H A R E^{\text {high }}$, the share of low skilled labour is denoted by $S H A R E^{\text {low }}$. There is evidence that adjustment costs for high skilled labour are larger compared to low skilled labour (see Hamermesh, 1993). On the one hand, one therefore might expect that firms with a large share of high skilled labour are more reluctant to change the number of employees when faced by demand variations than firms with a large share of low skilled labour. On the other hand, overtime work should be more common when the share of highly skilled labour is larger. Since firms are only asked whether they use enrolments or dismissals and not what types of skills are mainly affected, the study can only give qualitative rather than quantitative assessments.

(3) Expected, current and lagged demand changes. Since adjustments of the labour force are costly, one can expect that firms only adjust their workforce if they have been successively faced by changes in product demand. Therefore expected, current and lagged demand changes are introduced in the empirical model. One should expect that positive demand changes have a positive impact on labour demand and overtime work while a negative effect shows up for dismissals. The variables are constructed from the first part of the questionnaire, the lagged values are calculated from the related previous waves. Information on demand changes is provided on a three-point ordinal scale. $\quad D^{u p}{ }_{t}$ is coded one if increased demand is present (and zero otherwise) and $D^{\text {down }}{ }_{t}$ is coded one if decreased demand is realised (and zero otherwise). The subscript $t$ denotes the point in time to which the demand change corresponds. The lag length has been tested with likelihood-ratio tests so that the number of lagged demand changes included in the final specification differs across the estimations.

(4) Firm size. The adjustment of the labour force will presumably depend on firm size. Collective wage agreements can contain special small firm clauses which allow smaller firms to pay lower wages (Bispinck, 1999). The effect of firm size on employment and working hours adjustment is ambiguous. On the one hand, large firms may tend to both dismiss and hire workers more often than small firms, especially when the fixed part of the adjustment costs is large. On the other hand, the relationship between workers and management may be closer in small compared to large firms which may have an offsetting effect on labour demand. If the number of employees is small, adjustment patterns might in addition be different due to indivisibilities. In small firms, the decision to employ an additional worker might significantly influence the values $Y(1-\lambda)$ of the incumbent workers. The value of $Y(1-\lambda)$ for an additional employee might therefore be rather small when demand fluctuations are considered. Firm size is considered by the inclusion of five dummy variables which denote the size categories less than six $(S I Z E<6)$, between six and 20 (SIZE6-20), between 21 and 50 (SIZE20-50), between 51 and 100 (SIZE50-100), between 100 and 200 (SIZE100-200), and more than 
200 (SIZE > 200) employees. The second size class is the most densely populated one and serves as the base category.

(5) Bewilderment by demand variations. BEWILDER+ and BEWILDER++ take on the value one if the related firm states that it is affected or strongly affected by demand fluctuation, respectively. One can expect that, due to the existence of hiring and firing cost, firms are reluctant to adjust the labour force if affected by slight demand fluctuations only. Therefore, the effect of these two variables should be positive on enrolments and overtime work for example.

In order to control for further observable firm heterogeneity, the following set of variables is included in addition: (i) sector-specific influences are considered by nine sector dummy variables, technical planning serves as the base category; (ii) a dummy variable for East German firms (East Germany) and (iii) three wave-specific dummy variables Wave $_{11}$, Wave $_{15}$ and Wave 23 which take on the value one if the related observation was taken from the 11th, 15th or 23rd SSBS wave, respectively. Wave ${ }_{19}$ is the base category.

Due to unit and item non-response, the econometric analysis employs an unbalanced panel econometric approach in order to retain as much information as possible. The largest sample is the one related to the decision to subcontract orders and to temporary employment contracts as a reaction to demand variations. The corresponding estimates are based on 1,254 observations and 576 individuals. The figures for price adjustments, life-long working schemes, overtime/short-time work and free-lance employment are of similar size. Due to the inclusion of lagged demand changes, the number of observations and individuals for enrolments are lower. Although all questions on the extent to which the various instruments to adapt to demand changes are used are asked and answered on a five-point scale, the extreme category 'very often applied' is very thinly occupied in the case of dismissals and price adjustments. They both contain less than five percent of the observations (see Table A1). Following Blundell et al. (1993) the categories 'often applied' and 'very often applied' are combined into a single category often/very often applied'.

\section{Estimation results}

Economic and institutional determinants of firms employment and price policies

The results of the unbalanced random effects ordered probit models are presented in Table 3. Table 3 part one contains the estimation results for enrolments, dismissals, overtime/short-time work and for life-long working hours schemes, Table 3 (continued) displays the results for temporary employment contracts, subcontracting, free-lance work, and price adjustment. The estimations differ in the number of observations and the goodness of fit as 
measured by the pseudo $R^{2}$ (Aldrich and Nelson, 1989) which ranges from 0.0657 for the enrolments equation to 0.1608 for the price adjustment equation and which is quite convenient for those kinds of models. The standard deviation of the random effects, $\sigma_{\alpha}$, is significantly larger than zero in all models. Likelihood ratio tests of the random effects model (full model) against the pooled model (restricted model) indicate that the presence of random effects cannot be rejected at the one percent significance level in all specifications. Taking the panel structure into account therefore leads to efficiency gains. The threshold parameters $\mu$ are estimated with a high precision and are significantly different from one another in all equations.

The estimates confirm the influence of collective wage agreements on firm flexibility. Institutional factors have a significant effect on labour dynamics in German services firms. There are direct and secondary impacts of collective wage agreements as well. Neglecting institutions which change adjustment costs and policies of firms therefore will lead to purely specified empirical models of dynamic labour demand in Germany. Economic factors are important as well. Demand expectations, current and lagged demand changes, the skill structure and firm size influence firms use of alternative instruments.

The findings regarding the effects of collective wage agreements on firms use of instruments as a reaction to demand variations can be summarised as follows: 2

(i) the probability to hire additional labour and free-lance workers significantly decreases if firms are bound to collective wage agreements,

(ii) the probability to apply overtime/short-time work decreases if collective wage agreements are applied; the effect is, however, only weakly significant (p-value .10),

(iii) the probability for temporary employment contracts and life-long working schemes significantly increases if firms apply collective wage contracts and

(iv) the probabilities for dismissals, price adjustments and subcontracting do not differ across firms bound to collective wage agreements and those firms not applying collective wage contracts.

Hence, the empirical results indicate that firms which follow general wage agreements tend to be more reluctant to hire additional labour when faced by demand variations than those firms which are not bound to general wage agreements. Collective wage agreements seem to hamper firms' tendency to adjust to demand variations by using free-lance workers and seem to foster

\footnotetext{
${ }^{21}$ Given the number of observations and individuals, we regard a significance level below five percent as 'significant' and a level of five to ten percent as 'weakly significant'.

${ }^{22}$ All estimations have been performed in a restricted sample without the two sectors where collective wage agreements are very common (cargo handling and sewage disposal). The estimation results remain qualitatively the same and are thus not presented here.
} 
temporary employment contracts, which is in line with the hypotheses developed in Section 2. The application of collective wage agreements has neither a measurable influence on firms price setting behaviour nor on dismissals. The hypothesised positive impact on subcontracting has been rejected. Policy implications are discussed in the last section of this paper.

The other results capturing economic instead of institutional factors shall be briefly summarised. The coefficients corresponding to expected, lagged and current demand changes are in line with what could be expected a priori: for short-run instruments, such as overtime/short-time work, subcontracting, freelance working and price adjustment, mainly current demand changes matter. For the longer-term instruments such as enrolments and dismissals, expected and lagged demand changes play a significant role as well. The demand change variables are jointly significant at the five percent significance levels in all of the specifications with the exception of life-long working hours schemes. This latter finding indicates that life-long working hours schemes are intended to generally achieve more flexibility in working hours and employment.

Skill composition is important for the use of instruments to adapt to demand changes as well. Larger shares of low skilled labour significantly enhances the probability of dismissals and of temporary employment contracts. Larger shares of high skilled labour significantly enhances the probability of free lance workers and reduces the probability of price adjustments. The skill structure surprisingly has no significant impact on the use of enrolments and overtime/short-time. Firm size jointly matters in all but the subcontracting estimation, the price adjustment and the life-long working schemes equations. Firm size has a U-shaped effect on enrolments as well as on dismissals. Larger firms (size class 100 to 200 employees) use enrolments, dismissals, temporary employment contracts and over/short-time work more often than smaller firms. This indicates that employment flexibility is lower for very small compared to larger firms as one theoretically could expect if adjustment costs do not vary with the number of workers.

East German firms do significantly differ from their West German competitors in the use of the various instruments to adjust to demand changes. Their propensity to dismiss workers and to adjust prices is significantly higher than that of West German firms. The reverse is true for free lance workers. The sector affiliation dummies are jointly significant for all models. If firms are affected by demand changes to a higher degree (BEWILDER+, BEWILDER++) than dismissals, subcontracting and price adjustments occur with a higher probability. 
Table 3: Economic and institutional determinants of firms employment and price policies

\begin{tabular}{|c|c|c|c|c|c|c|c|c|}
\hline \multirow[b]{2}{*}{ COLLWAGE } & \multicolumn{2}{|c|}{$\begin{array}{l}\text { Life-long working } \\
\text { Schemes }\end{array}$} & \multicolumn{2}{|c|}{$\begin{array}{l}\text { Over/short/ } \\
\text { time }\end{array}$} & \multicolumn{2}{|c|}{ Dismissals } & \multicolumn{2}{|c|}{ Enrolments } \\
\hline & $0.391 * *$ & 0.16 & $-0.230^{*}$ & 0.14 & -0.117 & 0.14 & $-0.327 * *$ & 0.14 \\
\hline East Germany & $0.252 *$ & 0.15 & -0.490 & 0.13 & $0.446 * * *$ & 0.14 & -0.087 & 0.12 \\
\hline Wave $_{11}$ & -0.196 & 0.14 & 0.177 & 0.11 & 0.659 & 0.12 & -0.005 & 0.12 \\
\hline Wave $_{15}$ & 0.099 & 0.13 & 0.886 & 0.11 & 0.495 & 0.12 & -0.038 & 0.12 \\
\hline Wave $_{23}$ & 0.041 & 0.12 & 0.135 & 0.10 & -0.764 & 0.11 & 0.086 & 0.11 \\
\hline$S I Z E<5$ & -0.467 & 0.27 & $-0.672 * * *$ & 0.18 & 0.178 & 0.21 & $-0.338 *$ & 0.20 \\
\hline SIZE 6-20 & -0.174 & 0.13 & -0.122 & 0.12 & -0.133 & 0.11 & $-0.560 * * *$ & 0.14 \\
\hline SIZE50-100 & -0.092 & 0.18 & 0.127 & 0.15 & 0.239 & 0.18 & 0.115 & 0.17 \\
\hline SIZE100-200 & 0.107 & 0.21 & $0.492 * * *$ & 0.19 & $0.451^{* *}$ & 0.21 & $0.418^{* *}$ & 0.22 \\
\hline$S I Z E>200$ & 0.160 & 0.26 & $0.396 *$ & 0.22 & $0.505^{* *}$ & 0.24 & 0.243 & 0.21 \\
\hline$S H A R E^{u p}$ & -0.082 & 0.25 & 0.105 & 0.22 & -0.346 & 0.24 & 0.205 & 0.23 \\
\hline SHARE & 0.133 & 0.26 & -0.172 & 0.19 & $0.403 * *$ & 0.21 & 0.233 & 0.23 \\
\hline$B E W I L D E R^{+}$ & $0.205^{*}$ & 0.11 & 0.130 & 0.10 & $0.176^{*}$ & 0.11 & 0.128 & 0.11 \\
\hline$B E W I L D E R^{++}$ & 0.137 & 0.15 & 0.134 & 0.12 & $0.421 * * *$ & 0.14 & -0.039 & 0.14 \\
\hline$\Delta D+_{t+1}$ & & & & & -0.047 & 0.11 & $0.309 * * *$ & 0.12 \\
\hline$\Delta D-_{t+1}$ & & & & & 0.202 & 0.13 & -0.179 & 0.13 \\
\hline$\Delta D+{ }_{t}$ & & & $0.278 * * *$ & 0.10 & -0.137 & 0.11 & 0.190 & 0.12 \\
\hline$\Delta D-_{t}$ & & & -0.781 & 0.12 & $0.494 * * *$ & 0.13 & -0.215 & 0.15 \\
\hline$\Delta D++_{t-1}$ & & & & & $-0.150 * *$ & 0.07 & $0.290 * * *$ & 0.11 \\
\hline$\Delta D-_{t-1}$ & & & & & $0.150 * *$ & 0.07 & 0.059 & 0.12 \\
\hline \multicolumn{9}{|c|}{ Std. err. of random effect } \\
\hline$\sigma_{\alpha}$ & $1.143 * * *$ & 0.09 & $1.005 * * *$ & 0.07 & $0.961 * * *$ & 0.08 & 0.807 & 0.09 \\
\hline \multicolumn{9}{|c|}{ LR-tests for joint significancy } \\
\hline Sectoral dummies & \multicolumn{2}{|c|}{$19.410 * *$} & \multicolumn{2}{|c|}{$31.164 * * *$} & \multicolumn{2}{|c|}{$24.032 * * *$} & \multicolumn{2}{|c|}{$30.216^{* * *}$} \\
\hline Wave dummies & \multicolumn{2}{|l|}{5.918} & \multicolumn{2}{|c|}{3.256} & \multicolumn{2}{|c|}{2.164} & \multicolumn{2}{|c|}{1.508} \\
\hline Size class dum. & \multicolumn{2}{|l|}{5.828} & \multicolumn{2}{|c|}{$25.600^{* * *}$} & \multicolumn{2}{|c|}{$16.400 * * *$} & \multicolumn{2}{|c|}{$36.764 * * *$} \\
\hline Skill shares & \multicolumn{2}{|l|}{0.512} & \multicolumn{2}{|c|}{1.220} & \multicolumn{2}{|c|}{$7.658^{* *}$} & \multicolumn{2}{|c|}{4.605} \\
\hline Bewildern. dum. & \multicolumn{2}{|l|}{3.450} & \multicolumn{2}{|c|}{2.240} & \multicolumn{2}{|c|}{$9.888 * * *$} & \multicolumn{2}{|c|}{4.605} \\
\hline Demand dummies & & & \multicolumn{2}{|c|}{$11.246^{* * *}$} & 46.874 & & 10.640 & \\
\hline Pseudo- $\mathrm{R}^{2}$ and \# & obs. & & & & & & & \\
\hline Pseudo- $\mathrm{R}^{2}$ & 0.133 & & 0.12 & & 0.09 & & 0.06 & \\
\hline \# of obs. & 1,237 & & 1,24 & & 1,244 & & 992 & \\
\hline \# of individuals & 572 & & 579 & & 573 & & 482 & \\
\hline
\end{tabular}


Table 3: continued

\begin{tabular}{|c|c|c|c|c|c|c|c|c|}
\hline \multirow[b]{2}{*}{ COLLWAGE } & \multicolumn{2}{|c|}{$\begin{array}{c}\text { Temporary } \\
\text { employment contract }\end{array}$} & \multicolumn{2}{|c|}{ Free-lance workers } & \multicolumn{2}{|c|}{ Price adjustments } & \multicolumn{2}{|c|}{ Subcontracting } \\
\hline & $0.319 * *$ & 0.144 & $-0.409 * * *$ & 0.16 & 0.157 & 0.119 & 0.099 & 0.134 \\
\hline East Germany & 0.105 & 0.15 & $-0.338^{* * *}$ & 0.14 & $0.417 * * *$ & 0.111 & 0.105 & 0.140 \\
\hline Wave 11 & $-0.215^{*}$ & 0.13 & 0.020 & 0.14 & 0.077 & 0.115 & $0.232 * *$ & 0.111 \\
\hline Wave 15 & 0.170 & 0.13 & 0.129 & 0.13 & -0.132 & 0.110 & $0.303 * * *$ & 0.116 \\
\hline Wave $_{23}$ & 0.061 & 0.12 & -0.153 & 0.11 & 0.058 & 0.098 & -0.109 & 0.104 \\
\hline SIZE $<5$ & $-0.639 * * *$ & 0.22 & 0.577 & 0.24 & -0.154 & 0.171 & -0.096 & 0.202 \\
\hline SIZE 6-20 & -0.173 & 0.13 & 0.113 & 0.13 & 0.039 & 0.125 & $0.294 * * *$ & 0.123 \\
\hline SIZE50-100 & 0.250 & 0.18 & -0.056 & 0.17 & -0.033 & 0.132 & 0.003 & 0.163 \\
\hline SIZE $100-200$ & $0.416^{* *}$ & 0.21 & 0.094 & 0.22 & -0.020 & 0.177 & $0.402 * *$ & 0.208 \\
\hline$S I Z E>200$ & $0.729 * * *$ & 0.21 & $0.332 *$ & 0.21 & 0.217 & 0.183 & 0.200 & 0.209 \\
\hline$S H A R E^{\text {up }}$ & -0.120 & 0.27 & $0.997 * * *$ & 0.25 & $-0.376^{* *}$ & 0.196 & 0.295 & 0.223 \\
\hline SHARE & $0.867 * * *$ & 0.24 & 0.393 & 0.25 & -0.065 & 0.203 & 0.184 & 0.232 \\
\hline BEWILDER $R^{+}$ & -0.127 & 0.11 & 0.023 & 0.11 & $0.165^{*}$ & 0.096 & $0.188 * *$ & 0.099 \\
\hline BEWILDER $R^{++}$ & $0.273^{*}$ & 0.16 & 0.227 & 0.14 & $0.392 * * *$ & 0.128 & $0.387 * * *$ & 0.129 \\
\hline$\Delta D_{t+1}^{u p}$ & -0.048 & 0.13 & 0.099 & 0.13 & 0.193 & 0.114 & 0.224 & 0.148 \\
\hline$\Delta D^{\text {down }}{ }^{-}{ }_{t+1}$ & -0.079 & 0.12 & -0.025 & 0.13 & 0.017 & 0.109 & $0.233 * *$ & 0.106 \\
\hline$\Delta D^{u p}{ }_{t}$ & -0.004 & 0.12 & $0.179 *$ & 0.10 & -0.087 & 0.105 & $-0.238^{*}$ & 0.131 \\
\hline$\Delta D^{\text {down }}{ }_{t}$ & 0.057 & 0.16 & -0.096 & 0.15 & 0.101 & 0.123 & 0.102 & 0.108 \\
\hline
\end{tabular}

Std. err. of random effect

\begin{tabular}{l|ll|ll|ll|ll}
$\sigma_{\alpha}$ & $0.975^{* * *}$ & 0.08 & $1.090^{* * *}$ & 0.08 & 0.766 & 0.07 & $1.083^{* * *}$ & 0.07
\end{tabular}

LR-tests for joint significancy

\begin{tabular}{l|c|c|c|c} 
Sector. dum. & $34.528^{* * *}$ & $125.826^{* * *}$ & $42.756^{* * *}$ & $87.032^{* * *}$ \\
Wave dum. & $10.238^{* *}$ & $61.722^{* * *}$ & 5.392 & $21.964 * * *$ \\
Size class dum. & $30.214^{* * *}$ & $64.008^{* * *}$ & 2.992 & $11.516^{* *}$ \\
Skill Shares & $14.188^{* * *}$ & $73.318^{* * *}$ & 3.726 & 2.032 \\
Bewilder. dum. & $6.864^{* *}$ & $56.730^{* * *}$ & $10.596^{* * *}$ & $9.576^{* * *}$ \\
Demand dum. & 0.574 & $61.600^{* * *}$ & 4.642 & $14.458^{* * *}$
\end{tabular}

Pseudo $\mathrm{R}^{\mathbf{2}}$ and \# of obs.

\begin{tabular}{l|c|c|c|c} 
Pseudo $\mathrm{R}^{2}$ & 0.089 & 0.154 & 0.161 & 0.143 \\
\# of obs. & 1,254 & 1,250 & 1,236 & 1,254 \\
\# of individ. & 576 & 578 & 579 & 576 \\
\hline \hline
\end{tabular}

Notes: Maximum likelihood estimation of the random effects ordered probit model based on an unbalanced sample of services firms from the SSBS 1996 to $1999,4^{\text {th }}$ quarter. The specification also includes nine sector dummies. ***,**,* variable or groups of variables is significant at the $1,5,10$ percent level. 


\section{Determinants of applying collective wage agreements}

The empirical analysis concludes by uncovering factors explaining firms' propensity to apply collective wage agreements. A binary probit model for the probability that a firm applies collective wage agreements is estimated based on the 1999 sample of the SSBS. Sector dummies, firm size, skill mix, and firm age are included as explanatory variables. Table 4 displays coefficients, marginal effects and the respective standard errors of the probit estimate.

Sectoral affiliation is a major determinant of the application of collective wage agreements. The larger the share of high skilled labour and the smaller the share of low skilled labour, the smaller is the probability that a firm applies collective wage agreements. Firm age has a U-shaped, although insignificant, effect on the likelihood of applying general wage agreements. Firm size has a positive impact on the adaption of collective wage agreements. Summing up, the results indicate that the determinants to apply collective wage contracts in the business-related services sector are similar to those for the whole economy (see Bellmann et al., 1999). There is, however, one exception: in our study, East and West German firms do not differ in the application of collective wage agreements from one another. This is probably due to the fact that the business-related services sector lacks union tradition in both East and West Germany which goes along with lower attachments to collective wage bargaining.

\section{Table 4: Determinants of applying collective wage agreements}

\begin{tabular}{|c|c|c|c|c|}
\hline & Coeff. & Std. err. & Marg. eff. & Std. err. \\
\hline Computer \& rel. act. & -0.1366 & 0.2761 & -0.0411 & 0.0798 \\
\hline Tax consultancy & $-1.2269 * * *$ & 0.4229 & $-0.2473 * * *$ & 0.0436 \\
\hline Management cons. & 0.0016 & 0.2908 & 0.0005 & 0.0908 \\
\hline Architectural act. & -0.1254 & 0.3097 & -0.0377 & 0.0895 \\
\hline Advertising & -0.5074 & 0.3353 & -0.1339 & 0.0719 \\
\hline Vehicle rental & 0.1361 & 0.4149 & 0.0443 & 0.1403 \\
\hline Machine rental & 0.4238 & 0.3433 & 0.1472 & 0.1292 \\
\hline Cargo handling & $0.7995 * * *$ & 0.3153 & $0.2903 * * *$ & 0.1233 \\
\hline Sewage disposal & $0.6657 * * *$ & 0.2808 & $0.2364 * * *$ & 0.1079 \\
\hline East Germany & -0.0220 & 0.1757 & -0.0068 & 0.0545 \\
\hline SIZE5-49 & $-0.4889 * * *$ & 0.1920 & $-0.3417 * * *$ & 0.0981 \\
\hline SIZE $>99$ & $0.6607 * * *$ & 0.2284 & $0.2887 * * *$ & 0.1153 \\
\hline SHARE ${ }^{\text {high }}$ & $-1.0954 * * *$ & 0.3187 & $-0.1579 * * *$ & 0.0633 \\
\hline SHARE ${ }^{\text {low }}$ & $0.9254 * * *$ & 0.3680 & $0.2299 * * *$ & 0.0851 \\
\hline Age & -0.0075 & 0.0186 & -0.0023 & 0.0058 \\
\hline $\operatorname{Age}^{2}$ & 0.0002 & 0.0003 & 0.0001 & 0.0001 \\
\hline Constant & -0.1972 & 0.3572 & & \\
\hline
\end{tabular}

Notes: Maximum likelihood estimation probit model estimation based on SSBS data from $1999,2^{\text {nd }}$ quarter. *** variable is significant at the 1 percent level. 


\section{Conclusion}

The paper analyses the effect of collective wage agreements on the adjustment of working hours, employment and other input factors. Collective wage agreements might impose additional cost to the adjustment of labour, which may lead to more sluggish employment dynamics. Although the relationship between institutions and labour demand is particularly important for policies designed to create employment, empirical evidence is scarce at the firm-level. Our study is concerned with firms from the fast growing German businessrelated sector.

Our econometric findings indicate that collective wage agreements significantly decrease the probability of enrolling additional labour and of using overtime/short-time work, when firms are confronted with demand variations. Collective wage agreements also decrease firms' probability to hire free-lance workers. They significantly increase the use of temporary employment contracts and of life-long working hours schemes. We do not find significant effects on the application of dismissals, subcontracting and price adjustment. It has been further shown that enrolments are a widespread instrument for service firms to cope with demand fluctuations.

These results are based on qualitative rather than on quantitative information so that it cannot be inferred, e.g., how many workers are hired or dismissed due to positive or negative demand shocks. Our estimations results, however, indicate a significant impact of collective wage agreements on firms' employment policies. The transmission mechanism between collective wage agreements and firms employment policies nevertheless remains partly a black box and has to be investigated in greater detail for at least three reasons.

First, the influence of work councils could not explicitly be taken into account. Since work councils have a strong position as workers' representatives in issues related to employment and working hours, it is likely the case that work councils also have differential effects on firms' employment policies. Sadowski et al. (1995) find that the existence of work councils leads to less labour turnover within firms. Second, labour lawyers often point at the legal flexibility potentials already available in collective wage contracts (see Rieble, 1996). For example, collective wage agreements contain opening clauses, hardship clauses, lower tariffs for the formerly unemployed etc.. It therefore remains an open research question whether collective wage agreements are too inflexible per se or whether firms do not exhaust the range of legal possibilities for other reasons. One reason for not exhausting labour law might be the cost associated with actually exhausting labour law. Since the German labour law is complex its correct application presumably is costly. Third, the analysis is concerned with short-run labour dynamics. For a policy assessment of collective wage 
bargaining institutions, long-term implications are of course relevant as well. If collective wage agreements stabilise employee-employer relationships for employees and do not have negative impacts on overall employment, this is different to the case when stabilisation goes hand in hand with lower overall employment. Long-term implications of collective wage bargaining on labour demand have recently been investigated by Fitzenberger (1999), Fitzenberger and Franz (1999) and Klotz et al. (1999) using sectoral data. These studies find indications of insider-effects on wage setting with negative long-run effects on employment. Our qualitative results based on firm-level data are in line with these findings. Our results confirm the view that there is a trade-off between stable long-run employer-employee relationships for insiders and the creation of additional jobs in the short-run. Insider power creates specific barriers to new jobs and positive demand shocks has to be higher for firms bound to collective wage bargaining compared to other firms.

If the unification of five separate German services-related unions into one single service-sector union is successful, then collective wage agreements presumably will become more common in the services sector. More stable employment relationships of the employed workers might be one consequence, less enrolments in the face of demand positive fluctuations, may be another. It is not straightforward from the current analysis, however, to forecast the results of wage bargaining in the future with larger unions. If unions attach more weight to employment instead of wages (Fitzenberger and Franz, 1999) then the diffusion of collective wage bargaining might be positive for employment. Future research efforts should be devoted to study differential effects of collective wage agreements, work councils, employment protection rules and economic factors which lead to labour market rigidities in more detail. The focus should again be on the interplay of institutions and market forces on the firm level. 


\section{Appendix}

Table A1: Distribution of the possible answers across alternative instruments to adjust to demand changes

\begin{tabular}{|c|c|c|c|c|c|c|}
\hline & $\begin{array}{c}\text { not at all } \\
\text { applied }\end{array}$ & applied & $\begin{array}{c}\text { sometimes } \\
\text { applied }\end{array}$ & Applied & often applied & \# of obs \\
\hline \multicolumn{7}{|c|}{$\begin{array}{l}\text { Life-long working hours } \\
\text { scheme }\end{array}$} \\
\hline 1996 & 60.8 & 13.2 & 12.5 & 9.1 & 4.5 & 530 \\
\hline 1997 & 59.5 & 14.4 & 11.7 & 9.0 & 5.5 & 898 \\
\hline 1998 & 60.2 & 13.0 & 11.7 & 9.6 & 5.6 & 984 \\
\hline 1999 & 60.2 & 14.4 & 12.1 & 7.7 & 5.6 & 959 \\
\hline pooled & 60.1 & 13.8 & 11.9 & 8.8 & 5.4 & 3,371 \\
\hline \multicolumn{7}{|c|}{ Overtime/short-time } \\
\hline 1996 & 12.4 & 11.4 & 27.9 & 29.6 & 18.7 & 555 \\
\hline 1997 & 13.9 & 14.2 & 22.2 & 28.2 & 16.5 & 920 \\
\hline 1998 & 17.1 & 13.7 & 25.4 & 26.7 & 17.1 & 1,006 \\
\hline 1999 & 18.0 & 15.1 & 22.4 & 27.4 & 17.1 & 976 \\
\hline pooled & 15.8 & 13.9 & 25.4 & 27.7 & 17.2 & 3,457 \\
\hline \multicolumn{7}{|c|}{ Dismissals } \\
\hline 1996 & 38.0 & 28.7 & 20.9 & 9.6 & 2.9 & 555 \\
\hline 1997 & 41.2 & 26.8 & 20.9 & 7.9 & 3.2 & 919 \\
\hline 1998 & 41.6 & 27.8 & 20.4 & 7.2 & 3.1 & 1,001 \\
\hline 1999 & 49.4 & 24.2 & 16.8 & 7.3 & 2.3 & 969 \\
\hline pooled & 43.1 & 26.6 & 19.6 & 7.8 & 2.9 & 3,444 \\
\hline \multicolumn{7}{|c|}{ Enrolments } \\
\hline 1996 & 27.0 & 26.8 & 31.9 & 11.0 & 3.3 & 548 \\
\hline 1997 & 24.1 & 26.3 & 31.3 & 12.9 & 5.4 & 923 \\
\hline 1998 & 25.0 & 23.0 & 30.5 & 16.2 & 5.4 & 997 \\
\hline 1999 & 22.8 & 25.9 & 30.3 & 14.5 & 6.6 & 967 \\
\hline pooled & 24.4 & 25.3 & 30.9 & 14.0 & 5.4 & 3,435 \\
\hline \multicolumn{7}{|c|}{ Temporary employment contracts } \\
\hline 1996 & 35.9 & 18.1 & 24.6 & 15.8 & 5.6 & 552 \\
\hline 1997 & 32.0 & 18.4 & 22.4 & 17.3 & 9.9 & 934 \\
\hline 1998 & 33.6 & 18.0 & 22.0 & 18.6 & 7.9 & 1,001 \\
\hline 1999 & 36.9 & 17.4 & 20.1 & 17.1 & 8.5 & 973 \\
\hline pooled & 34.5 & 18.0 & 22.0 & 17.4 & 8.2 & 3,460 \\
\hline \multicolumn{7}{|c|}{ Free-lance contractors } \\
\hline 1996 & 38.1 & 14.9 & 18.7 & 17.6 & 10.8 & 557 \\
\hline 1997 & 38.6 & 17.5 & 16.2 & 15.6 & 12.1 & 935 \\
\hline 1998 & 41.4 & 15.7 & 16.9 & 16.0 & 10.1 & 1,001 \\
\hline 1999 & 42.6 & 14.5 & 17.3 & 17.0 & 8.6 & 975 \\
\hline pooled & 40.4 & 15.7 & 17.1 & 16.4 & 10.3 & 3,468 \\
\hline \multicolumn{7}{|c|}{ Price adjustments } \\
\hline 1996 & 27.9 & 24.6 & 29.2 & 13.7 & 4.6 & 548 \\
\hline 1997 & 33.4 & 22.6 & 27.8 & 12.8 & 3.4 & 921 \\
\hline 1998 & 28.2 & 25.1 & 28.1 & 13.8 & 4.7 & 992 \\
\hline 1999 & 29.7 & 26.1 & 26.6 & 13.6 & 4.1 & 963 \\
\hline pooled & 30.0 & 24.6 & 27.8 & 13.5 & 4.2 & 3,424 \\
\hline \multicolumn{7}{|c|}{ Subcontracting } \\
\hline 1996 & 25.8 & 21.9 & 24.7 & 17.6 & 10.1 & 567 \\
\hline 1997 & 24.0 & 22.8 & 24.0 & 20.2 & 9.1 & 939 \\
\hline 1998 & 30.5 & 22.7 & 23.1 & 15.3 & 8.4 & 1,003 \\
\hline 1999 & 30.0 & 21.3 & 22.7 & 17.8 & 8.1 & 970 \\
\hline pooled & 27.8 & 22.2 & 23.5 & 17.7 & 8.8 & 3,479 \\
\hline
\end{tabular}


\# of obs. Mean/Share Std. err. Type

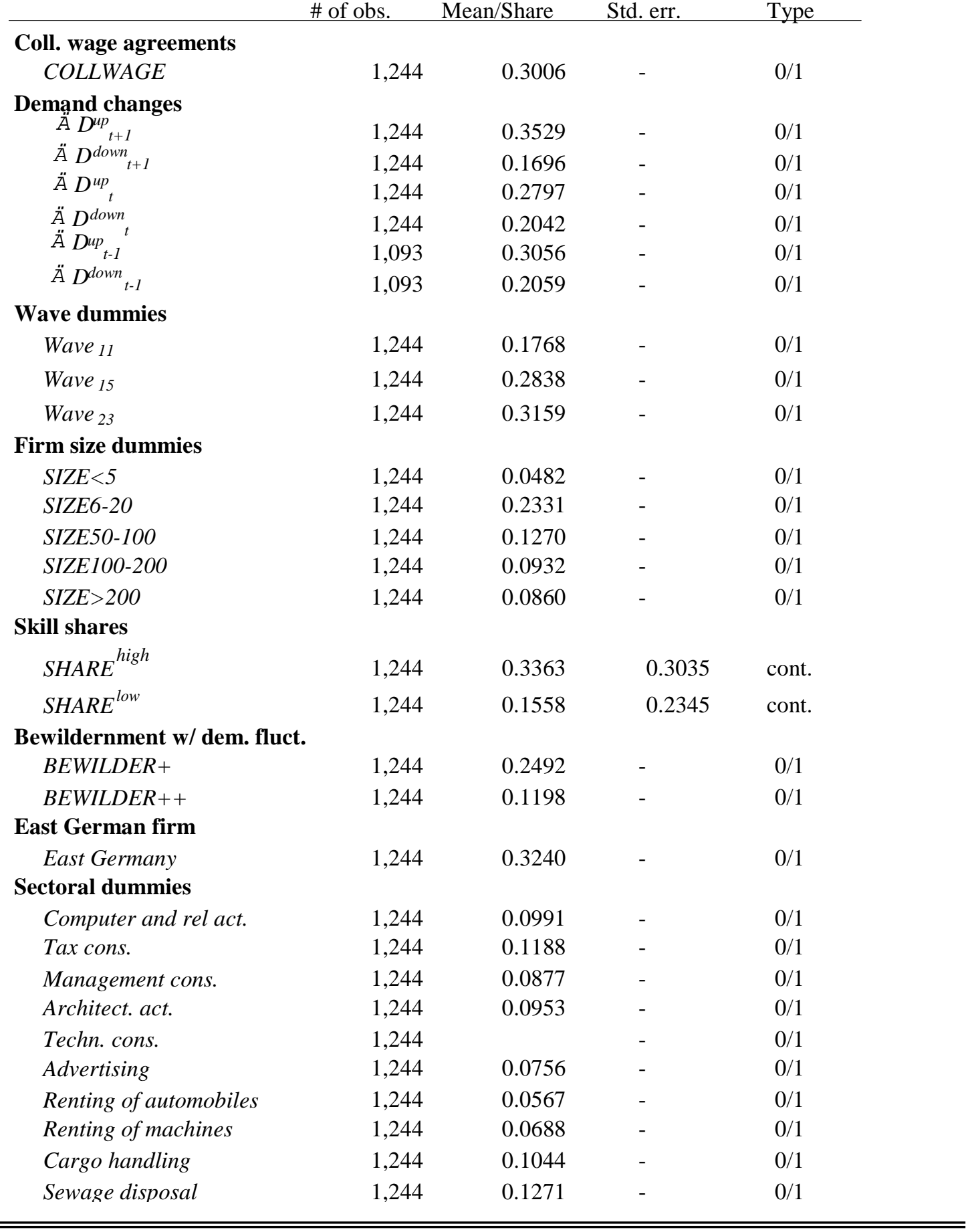




\section{References}

Aldrich, J.H., and F.D. Nelson (1989), Linear Probability, Logit and Probit Models, Sage University Press, Beverly Hills.

Bellmann, L. S. Kohaut, and C. Schnabel (1999), Flächentarifvertrag im Zeichen von Abwanderung und Widerspruch: Geltungsbereich, Einflußfaktoren und Öffnungstendenzen, in: L. Bellmann and V. Steiner (eds.) Panelanalysen zu Lohnstruktur, Qualifikation und Beschäftigungsdynamik, Nürnberg: BeitrAB 229, 11-40.

Bispinck, R. (1999), Collective Wage Bargaining in Germany 1988/1999, WSI discussion paper No. 76.

Blundell, R., F. Laisney, and M. Lechner (1993), Alternative Interpretations of Hours Information in an Econometric Model of Labour Supply, Empirical Economics, 18, 393-415.

Davis S. J. and J. Haltiwanger (1999), On the Driving Forces Behind Cyclical Movements inEmployment and Job Reallocation, American Economic Review, Vol. 89, 5, $1234-1258$.

Dietrich, H. (1998), Erwerbsverhalten in der Grauzone von selbständiger und abhängiger Erwerbsarbeit, Nürnberg: BeitrAB 205.

Farber, H.S. (1999), Mobility and Stability: the Dynamics of Job Change in Labour Markets, in:

O. Ashenfelter and D. Card (eds.), Handbook of Labour Economics, NorthHolland: Elsevier, 2439-2483.

Fitzenberger, B. (1999), Wages and employment across skill groups. An Analysis for West Germany, Heidelberg: Physica (ZEW-Economic Studies, Vol. 6).

Fitzenberger, B. and W. Franz (1999), Industry-Level Wage Bargaining: A Partial Rehabilitation- The German Experience, Scottish Journal of Political Economy, Vol. 46(4), 419 - 436.

Fitzenberger, B., I. Haggeney and M. Ernst (1999), Wer ist noch Mitglied in Gewerkschaften?, Zeitschrift für Wirtschafts- und Sozialwissenschaften, 119(2), 223-264.

Franz, W. (1999), Arbeitsmarktökonomik, Berlin: Springer (4. ed.).

Franz, W. and W. Smolny (1994), Sectoral Wage and Price Formation and Working Time in Germany: An Econometric Analysis, Zeitschrift für Wirtschafts- und Sozialwissenschaften, 114, 4,507 - 529.

Greene, W.H. (1995), Limdep 7.0 User's Manual, Econometric Software Inc., New York.

Greene, W.H. (1997), Econometric Analysis, Prentice-Hall, Upper Saddle River. Hamerle, A., and G. Ronning (1995), Panel Analysis for Qualitative Variables, in: G. Arminger, C.C. Clogg, and M.E. Sobel (eds.), Handbook of Statistical Modelling for the Social and Behavioural Sciences, Plenum Press, 401-452. 
Hamermesh, D. S. (1993), Labour Demand, Princeton University Press: Princeton, New Jersey.

Hamermesh, D. S. and G. Pfann (1996), Adjustment Costs in Factor Demand, Journal of Economic Literature, 34(3), 1264-1292.

Houseman, S., and K. Abraham (1995), Labour Adjustment und Different Institutional Structures, in: Buttler, F.W., W. Franz, R. Schettkat, and D. Soskice (Eds.): Institutional Frameworks and Labour Demand Performance, London.

Hausman, J.A., A.W. Lo, and A.C. MacKinlay (1992), An Ordered Probit Analysis of Transaction Stock Prices, Journal of Financial Economics 31, 319-379.

Kaiser, U., M. Kreuter and H. Niggemann (2000), Calculating Expansion Factors for a Business Survey in the Business-Related Services Sector, ZEW discussion paper No. 00-22.

Klodt, H., R. Maurer, and A. Schimmelpfennig (1997), Tertialisierung der deutschen Wirtschaft. J.C.B. Mohr, Tübingen.

Klotz, S., F. Pfeiffer, and W. Pohlmeier (1999), Zur Wirkung des technischen Fortschritts auf die Qualifikationsstruktur der Beschäftigung und die Entlohnung, Journal of Economics and Statistics 219(1+2), 90-108.

König, H. and W. Pohlmeier (1988), Employment, Labour Utilization and Procyclical LabourProductivity, Kyklos, 41(4), 551-572.

Kraft, K. (1989), Quasi-Fixity of White-Collar and Blue-Collar Workers and of Their Hours of Work in West-German Manufacturing Industries, Journal of Institutional and Theoretical Economics, 143, 477-496.

Layard, S. and S. Nickell (1999), Unemployment: Macroeconomic Performance and the Labour Market, in: O. Ashenfelter and D. Card (Eds.): Handbook of Labor Economics Vol. 3, Amsterdam.

Pfeiffer, F. (2000), Training and Individual Performance in Europe: Evidence from Microeconomic Studies, forthcoming in M. Tessaring (ed.) Training for a changing society-2. Report on vocational education and training research in Europe, CEDEFOP.

Pfeiffer, F. and M. Falk (1999), Der Faktor Humankapital in der Volkswirtschaft. ZEW,Wirtschaftsanalysen Vol. 35, Nomos-Verlag, Baden-Baden.

Rieble, V. (1996) Arbeitsrecht und Wettbewerb ('Labour law and competition'), Heidelberg: Springer.

Sadowski, D., U. Backes-Gellner, and B. Frick (1995), Work Councils: Barriers or Boosts for the Competitiveness of German Firms?, British Journal of Industrial Relations 33(3), 493-513. 